Tilaar, H.A.R. (2009). Kekuasaan dan Pendidikan: Manajemen Pendidikan Nasional dalam Pusaran Kekuasaan. Jakarta: Rineka Cipta.

Tilaar, H.A.R. dan Riant Nugroho. (2009). Kebijakan Pendidikan: Pengantar untuk Memahami Kebijakan Pendidikan dan Kebijakan Pendidikan sebagai Kebijakan Publik. Yogyakarta: Pustaka Pelajar. Cet. II.

Undang-Undang No. 20 tahun 2003 tentang Sistem Pendidikan Nasional.

Undang-Undang No. 32 tahun 2004 tentang Pemerintah Daerah.

Undang-Undang No. 14 tahun 2005 tentang Guru dan Dosen.

\section{INTERNALISASI NILAI MULTIKULTURALISME \\ DAN KERUKUNAN ANTARUMAT BERAGAMA DALAM MASYARAKAT}

Oleh:

Syukri Fathudin Achmad Widodo \& Vita Fitria

Universitas Negeri Yogyakarta

Email:syukri_widodo@yahoo.com

\begin{abstract}
This research discussed on how the tolerance between societies can be created through the pattern and process of the internalization of multiculturalism value to society in Potorono, Banguntapan, Bantul. The values appeared through such a long processes of society dynamic where they lived. In descriptive qualitative method, the portrait of that society can be revealed to analyze deeper the practices or processes of the internalization of multiculturalism value that can unite the society with their differences. This research aimed at revealing casuistically the process of the internalization of multiculturalism value and its correlation with tolerance between societies, as well as the factors which influence the societies to maintain their multiculturalism value. The objective of this research is to know the processes of internalization of multiculturalism value and to understand its correlation with tolerance in society, thus it can be an interactive room for each people in society to find the solution and alternative answer for any possible conflict that may be happened. This research applied qualitative research which aimed at gaining deeper understanding on the phenomenon recorded on the field of the research. To understand deeply and holistically, the analysis of meanings, values and deeper understanding on the character of society of Potorono, Banguntapan, Bantul is needed. The approach applied in this research is exploratory descriptive and explanatory study case. It is through exploratory the data found in the research, then explaining the data found and final process is improving the explanations comparatively to certain similar phenomenon and proving that this kind of explanation can be applied to another situation. The research findings are: 1) the awareness of society of Potorono to maintain the values of tolerance has been there
\end{abstract}


for long time ago and has been practiced hereditarily 2) the social interaction with a new community happened with adaptive process and step by step through religious and social activities, 3) the majority of native people have kinship relation, thus it caused the process of internalization of value easier, 4) the values appeared are tolerance, togetherness, care and respectfulness.

Keywords: Multiculturalism, interfaith tolerance

\section{PENDAHULUAN}

Indonesia dikenal sebagai negara dengan sosok masyarakatnya yang pluralistik dan menyimpan nuansa kemajemukan dalam hal agama, suku, tradisi, kesenian, kebudayaan, cara hidup dan pandangan nilai yang dianut oleh kelompok-kelompok etnis dalam masyarakat Indonesia. Pada satu sisi, kemajemukan itu dapat menjadi sebuah dinamika kekuatan positif dan konstruktif apabila diarahkan secara positif dan konstruktif pula. Pada sisi lain, ia dapat menjadi sebuah kekuatan yang negatif dan destruktif apabila tidak dikelola dan diarahkan secara positif. Hal ini tampaknya sangat disadari oleh para pendiri republik ini. Itulah sebabnya, setelah melalui perdebatan konstitusional yang panjang, para pendiri republik ini tidak mendirikan Negara Indonesia sebagai negara agama, tetapi mereka sepakat memilih dan menetapkan Pancasila sebagai dasar dan falsafah negara. Dengan demikian, negara Indonesia dikenal sebagai negara Pancasila, suatu negara yang tidak bercorak teokratis tetapi juga tidak bersifat sekular (Faisal Ismail, 2002: 190191).

Kemajemukan bangsa dan masyarakat Indonesia setidaktidaknya meliputi hal-hal sebagai berikut: Secara geografis, terdiri atas 13.667 pulau baik yang dihuni maupun yang tidak. Secara etnik, Indonesia terdapat 358 suku bangsa dan 200 sub suku bangsa. Dilihat dari jumlah pemeluk agamanya, berdasarkan sensus penduduk tahun 2010, prosentase jumlah pemeluk agama di
Indonesia yakni: Islam 87,18\%, Kristen 6,96\%, Katolik 2,91\%, Hindu $1,69 \%$, Budha $0,72 \%$, Kong Hu Chu $0,05 \%$, penganut ajaran lain $0,13 \%$ dan yang tidak jelas $0,092 \%$. Adapun di wilayah Daerah Istimewa Yogyakarta sendiri prosentase penganut agama bisa dilihat sebagai berikut, Islam 91,95\%, Kristen 2,73\%, Katholik 4,79\%, Hindu 0,15\%, Budha 0,10\%, Kong Hu Chu 0,00\%, ajaran lain $0,01 \%$, dan yang tidak jelas $0,26 \%$ (BPS, 2010).

Menilik kemajemukan dan beragamnya masyarakat Indonesia, tentu bukan persoalan mudah hidup berdampingan satu sama lain di negeri yang penuh dengan keragaman suku, ras, etnis dan agama ini. Dibutuhkan kesediaan saling menghargai dan menghormati perbedaan di antara mereka. Untuk mewujudkan realita kebersamaan dalam perbedaan tersebut, dibutuhkan internalisasi nilai multikultural dalam masyarakat. Pasalnya, setiap suku, ras, etnis, dan agama memiliki nilai dan cara mengaplikasikannya sendiri-sendiri. Louis O. Kattsoff menyatakan, terdapat banyak cabang pengetahuan yang bersangkutan dengan masalah nilai yang khusus seperti ekonomi, estetika, etika, filsafat agama dan epistemologi. Epistemologi berkaitan dengan masalah kebenaran, etika bersangkutan dengan masalah kebaikan (dalam arti kesusilaan), dan estetika bersangkutan dengan masalah keindahan (Kattsoff, 1996: 327). Sesuatu benda atau perbuatan dapat mempunyai nilai, sehingga dapat dinilai. Hal-hal tersebut dapat mempunyai nilai karena mengandung nilai atau menggambarkan suatu nilai. Suatu pernyataan mempunyai nilai kebenaran, dan karena itu bernilai untuk pemberitahuan. Maka dapat dikatakan perkataan "nilai" kiranya mempunyai makna: seperti 1). Mengandung nilai (artinya, berguna), 2).Merupakan nilai (artinya, "baik" atau "benar" atau "indah"), 3).Mempunyai nilai (artinya, merupakan obyek keinginan, mempunyai kualitas yang dapat menyebabkan orang mengambil sikap "menyetujui", atau mempunyai sifat nilai tertentu), dan 4).Memberi nilai (artinya, 
menanggapi sesuatu sebagai hal yang diinginkan atau sebagai hal yang menggambarkan nilai tertentu) (Kattsoff, 1996: 332).

Sebagaimana diketahui, Daerah Istimewa Yogyakarta merupakan wilayah yang setiap tahun bertambah jumlah pendatangnya dari berbagai daerah. Hal ini menyebabkan terjadinya akulturasi budaya dan heterogenitas masyarakat yang setiap saat mengalami perkembangan. Dengan banyaknya pendatang, baik pelajar, mahasiswa, maupun pekerja yang tinggal di wilayah kampung-kampung di Yogyakarta, otomatis proses interaksi masyarakat juga mengalami perubahan. Kegiatan-kegiatan rutin baik gotong royong, ronda malam, atau kegiatan-kegiatan ritual yang semula dilakukan oleh seluruh masyarakat kampung, menjadi terkikis karena faktor para pendatang yang sebagian tidak mampu membaur dengan penduduk asli. Bisa dianalisa, hal tersebut disebabkan oleh beberapa faktor, antara lain : 1). Pendatang/mahasiswa tidak membaur karena merasa bukan warga kampung, begitu juga sebaliknya, warga kampung menganggap mahasiswa hanya warga sementara, jadi merasa tidak terlalu penting untuk dilibatkan. 2). Dengan munculnya komplek-komplek perumahan di tengah kampung, muncul komunitas baru yang termasuk kelompok elit dengan status terpandang yang sulit bisa bergabung dengan warga kampung. Di lain pihak, warga kampungpun enggan untuk membaur dengan lingkungannya. 3). Kondisi ekonomi yang tidak stabil menyebabkan para pekerja dengan sangat ekstra. Masing-masing punya tujuan untuk meningkatkan taraf hidup keluarga. Kondisi ini menyebabkan orang tua yang bekerja jarang bisa membaur dengan warga sekitar, kalau toh ada hari libur, biasanya dimanfaatkan untuk liburan bersama keluarga.

Kampung Potorono yang berada di Kecamatan Banguntapan Kabupaten Bantul, masyarakatnya memiliki perbedaan budaya dan agama. Warga kampung Potorono, baik penduduk asli maupun pendatang menunjukkan sikap saling toleransi dan menghargai atas apa yang mereka lakukan. Sikap keseharian selalu cair dan tidak mempedulikan siapa warga asli, siapa pendatang, atau siapa yang muslim, nonmuslim, pegawai atau buruh sekalipun. Multikultur yang mereka bangun bukan untuk sesuatu yang direkayasa sehingga menjadi rigid, melainkan sesuatu yang embodded (menyatu) dalam keseharian mereka. Perbedaanperbedaan tersebut justru mampu menjadikan energi perbedaan itu sebagai kekuatan pemersatu di antara mereka. Melihat fenomena itu, sudah barang tentu ada nilai-nilai yang sedang diperjuangkan bersama-sama di tengah perbedaan antar nilai pada masyarakat itu. Adapun implikasi dari itu, adalah terciptanya kerukunan antarumat beragama khususnya, dan kerukunan antaretnis pada umumnya.

Penelitian ini memfokuskan pada masyarakat kampung Potorono Banguntapan Bantul sebagai lokasi penelitian dan menjadikan tema internalisasi nilai multikulturalisme dan kerukunan antarumat sebagai obyek materialnya. Alasan mendasar dipilihnya kampung Potorono kecamatan Banguntapan kabupaten Bantul Daerah Istimewa Yogyakarta, karena wilayah Bantul merupakan salah satu wilayah yang masih padat oleh mayoritas masyarakat asli Bantul. Berbeda dengan wilayah Kabupaten Sleman dan Kodya Yogyakarta yang mayoritas wilayahnya sudah dipenuhi oleh pendatang yang menuntut ilmu dan kemudian menetap. Di wilayah Potorono, kepadatan penduduk meningkat bukan karena pendatang yang berprofesi sebagai mahasiswa, melainkan keluarga yang mencari lokasi dengan harga lebih terjangkau dibanding dengan di kota. Atau keluarga yang menghindari kepadatan penduduk dan bisingnya kendaraan, karena wilayah ini terhitung wilayah pinggiran yang masih jauh dari polusi dan kemacetan lalu lintas.

Kampung Potorono memiliki keunikan, seperti keberadaan multipartai, mulai memadatnya penduduk pendatang, dan keragaman agama tidaklah membuat kampung tersebut bergejolak. Di samping itu, kampung yang dahulunya relatif dipenuhi oleh 
model kepercayaan Jawa mulai mampu beradaptasi secara perlahan dengan perkembangan agama-agama lain yang ikut meramaikan suasana para pemeluk di dalam mencapai kehidupan harmoni dan cita-cita sosial. Penerimaan mereka terhadap sesuatu hal yang baru tidaklah membuatnya meninggalkan tradisi yang sudah berjalan, tetapi melakukan kombinasi atas sesuatu yang baru. Dalam konteks nilai, mereka memadukan nilai-nilai yang baru dengan prinsip nilai mereka sendiri.

Penelitian bertema Internalisasi Nilai Multikulturalisme dan Kerukunan Antarumat dalam Masyarakat Jawa: Studi Kasus pada Masyarakat Potorono, Banguntapan, Bantul Daerah Istimewa Yogyakarta, lebih menyoal pada internalisasi nilai tidak hanya pada perbedaan agama, tapi juga perbedaan struktur sosial kemasyarakatan dalam menyikapi perbedaan antara penduduk asli dan pendatang. Penelitian ini secara cermat mengamati bagaimana pola dan proses internalisasi nilai multikulturalisme dalam masyarakat Kampung Potorono Banguntapan Bantul. Serta meneliti faktor apa saja yang melatarbelakangi masyarakat mempertahankan nilai multikulturalisme dan kerukunan antarumat. Penelitian ini bertujuan untuk mengetahui proses internalisasi nilai multikulturalisme dan memahami korelasinya dengan kerukunan antarumat. Sehingga dari sini dapat membuka ruang interaktif antarindividu di masyarakat di dalam menemukan solusi dan alternatif penyelesaian jika suatu saat terjadi konflik di tengah masyarakat.

\section{CARA PENELITIAN}

Jenis penelitian ini adalah qualitative research yang dilaksanakan pada tanggal 1 April 2011 sampai 30 Oktober 2011 di Kampung Potorono, Kelurahan Potorono, Kecamatan Banguntapan, Kabupaten Bantul, DIY. Subjek penelitian ini adalah warga yang tinggal di Kampung Potorono mulai dari para tokoh sampai masyarakat umum baik penduduk asli maupun pendatang, 44 muslim maupun nonmuslim. Untuk memahami secara lebih dalam dan menyeluruh, tidak cukup dengan hanya melihat adanya hubungan sebab akibat dari beberapa variabel yang diajukan, melainkan harus digali makna, nilai-nilai, dan pemahaman yang lebih dalam terhadap pandangan hidup dan karakter masyarakat Potorono Banguntapan Bantul, sehingga akan diperoleh pemahaman yang lebih dalam terhadap pertanyaan-pertanyaan yang diajukan dalam penelitian. (Varma, 1982: 101).

Penelitian ini merupakan grounded theory yaitu penelitian lapangan dengan análisis secara induktif dengan pendekatan holistik. Data hasil wawancara yag terkumpul direduksi melalui pemilahan, penyederhanaan, kemudian ditransformasi ke dalam bentuk tulisan yang disajikan dalam teks naratif. Peneliti selalu mengambil kesimpulan dalam setiap pereduksian data hingga memunculkan suatu kesimpulan yang bisa dijadikan sebagai hasil akhir penelitian (Miles, MB dan AM Huberman: 1992). Adapun cara menguji validitas datanya adalah melakukan : pendekatan diri dengan informan sehingga dapat mengurangi subjektivias informasi yang diberikan; melakukan diskusi dengan peneliti lain dalam hal penelitian sejenis; serta melakukan triangulasi atau pengecekan terhadap kebenaran informasi dari beberapa informan secara intensif (Maleong: 1991). Dalam pengumpulan data lapangan, peneliti menggunakan tahapan-tahapan sebagai berikut : a). Partisipatoris, yakni peneliti menjadi bagian dari yang diteliti. Penelitian partisipatoris bersifat kualitatif dan dasarnya adalah tindakan komunikatif (Mochtar Bukhori, 1993). Dengan cara ini peneliti akan lebih leluasa mengamati fenomena yang ada di lingkungan Kampung Potorono secara lebih dekat dan leluasa sehingga dapat memaksimalkan perolehan infomasi. Cara ini pula akan bisa memahami fenomena di lapangan secara lebih mendalam sehingga tidak terjadi bias tafsir terhadap simbol dan tradisi yang berlaku di wilayah tersebut. b). Indepth interview atau wawancara langsung dan mendalam terhadap pihak-pihak yang kompeten. 
Peneliti melakukan wawancara kepada 8 orang responden dari berbagai unsur mulai masyarakat umum yang terdiri dari penduduk asli dan warga muslim sebagai subjek mayor, pendatang dan warga nonmuslim sebagai subjek minor. c). Observasi, yaitu pengamatan langsung terhadap lokasi penelitian dalam hal ini Kampung Potorono. Observasi dilakukan dengan mencermati fenomenafenomena yang mengemuka dengan berinteraksi secara langsung dan intensif dengan warga Kampung Potorono. d). Dokumentari yakni inventarisasi dan menelaah data dokumen yang dimungkinkan dapat memberi informasi, penjelasan, dan rujukan terhadap topik penelitian. Dokumen bisa berupa dokumen pribadi maupun dokumen yang ada di instansi atau lembaga misalnya datadata yang didapat dari Kantor Kelurahan ataupun arsip-arsip dari Kepala Dusun dan Ketua RT setempat.

\section{PEMBAHASAN}

Desa Potorono merupakan bagian integral dari wilayah Kecamatan Banguntapan, Kabupaten Bantul, Propinsi Daerah Istimewa Yogyakarta. Desa Potorono memiliki wilayah seluas 390.0550 ha. Adapun batas-batas wilayahnya bagian Utara Desa Sendangtirto Berbah Sleman, bagian Timur Desa Sitimulyo Piyungan, bagian Selatan Desa Jambidan, bagian Barat Desa Baturetno dan Desa Wirokerten. Orientasi Desa jarak Kantor Pemerintahan Desa Potorono dengan Kantor Kecamatan Banguntapan sejauh $3 \mathrm{Km}$, ke Kantor Kabupaten Bantul $15 \mathrm{Km}$, dan ke Kantor Propinsi DIY 9 Km.(Data dari Biro Pusat Statistik Kab. Bantul, tahun 2010).

Secara Administratif, Pemerintahan Desa Potorono terbagi dalam 9 Dusun dengan jumlah penduduk sekitar 12.169 jiwa sebagaimana bisa dilihat dalam Tabel 1 .
Dalam hal penelitian ini, yang penulis jadikan sebagai objek penelitian adalah Dusun Potorono (dalam tabel no urut 1), dan lebih spesifik lagi adalah wilayah Kampung Potorono.

\section{Tabel 1. Jumlah Penduduk Desa Potorono}

\begin{tabular}{|l|l|r|r|}
\hline No & \multicolumn{1}{|c|}{ Dusun } & $\begin{array}{r}\text { Jumlah } \\
\text { Penduduk }\end{array}$ & \multicolumn{1}{c|}{ Persentase } \\
\hline 1. & Potorono & 1.611 & 13,24 \\
\hline 2. & Salakan & 1.481 & 12,17 \\
\hline 3. & Prangwedanan & 1.169 & 9,61 \\
\hline 4. & Condrowangsan & 1.601 & 13,16 \\
\hline 5. & Mertosanan Wetan & 1.148 & 9,43 \\
\hline 6. & Nglaren & 1.065 & 8,75 \\
\hline 7. & Mertosanan Kulon & 1.931 & 15,87 \\
\hline 8. & Balong Lor & 1.103 & 8,71 \\
\hline 9. & Banjardadap & 1.103 & 9,06 \\
\hline
\end{tabular}

- Data tahun 2010, diambil dari data Kelurahan Potorono.

Dusun Potorono dengan jumlah penduduk kurang lebih 1600 orang terdiri dari 4 RT (Rukun Tetangga), yaitu Rt 1, Rt 2, Rt 3 dan Rt 4. Tidak seperti komunitas desa pada umumnya, untuk wilayah Potorono ini tidak ada RW (Rukun Warga), semua tergabung dalam RT (Rukun Tetangga) yang masing-masing RT mempunyai jumlah anggota yang banyak dan beragam. Khusus Rt 4 disebut daerah Botokan, letaknya berjauhan dengan $3 \mathrm{Rt}$ yang lain. Sedangkan Rt 1, Rt 2 dan Rt 3 terletak dalam satu wilayah Kampung yang masyarakat biasa menyebutnya dengan Potorono Lor untuk Rt 1, Potorono Tengah untuk Rt 2 dan Potorono Kidul untuk Rt 3. Ketiga wilayah Rt tersebut yang selanjutnya penulis sebut dengan Kampung Potorono yang penulis jadikan sebagai objek kajian penelitian ini. 
Diperkirakan data jumlah Kepala Keluarga (KK) untuk RT 1 sebanyak $150 \mathrm{KK}$, RT 2 sebanyak $130 \mathrm{KK}$ dan RT 3 sebanyak 160 KK. Masing-masing RT mempunyai Ketua RT yang menangani permasalahan dan kegiatan di wilayahnya. Namun tak jarang untuk kegiatan-kegiatan tertentu dilakukan secara bersamabersama, misalnya syawalan bersama dalam satu masjid, acara mertidusun yang dihadiri oleh dan untuk semua warga kampung, atau kegiatan PKK berupa arisan rutin dan posyandu yang diadakan tiap bulan.

Di Kampung Potorono tidak ditemui hilir mudik mahasiswa tempat-tempat kost yang berderetan sebagaimana ditemui di wilayah kota atau kabupaten Sleman. Di wilayah ini belum ada kampus atau sekolah-sekolah favorit yang menjadi rujukan masyarakat. Hanya ada satu dua tempat kost untuk para pekerja / buruh pabrik berasal dari wilayah yang cukup jauh dari lokasi. Ada satu pabrik besar berada di wilayah Potorono ini adalah PT Komitrando (Korea Mitra Indonesia) yang bergerak di bidang pengadaan assesoris serta pembuatan gloves (sarung tangan). Mayoritas para pekerjanya berasal dari wilayah sekitar. Keragaman warga kampung bisa dilihat dari agama, profesi dan katagori penduduk asli atau pendatang. Untuk memahami lebih rinci bagaimana kondisi dan hubungan antarwarga, peneliti membagi dalam dua pembahasan, yaitu hubungan antarwarga dalam wilayah agama dan hubungan antarwarga dalam wilayah sosial kemasyarakatan.Untuk melihat lebih jauh tentang kondisi dan hubungan antaragama di wilayah kampung Potorono, sebaiknya diihat Tabel 2.

Tabel tersebut menjelaskan bahwa mayoritas warga memeluk agama Islam. Warga non muslim hanya beberapa persen saja dan rata-rata beragama Kristen dan Katholik. Menurut informasi yang penulis dapatkan tidak ditemukan warga yang beragama lain selain ketiga agama tersebut. Sebagai agama mayoritas, pemahaman masing-masing muslim terhadap Islam pun berbeda-beda. Ada yang menjalani tuntunan-tuntunan Islam secara syar'i dan rutin dalam menjalankan aktivitas keagamaannya, ada yang setengah-setengah hanya kalau mau dan sempat saja, namun banyak juga yang sekedar Islam KTP, tidak pernah menjalankan syariat Islam sebagaimana seharusnya. Dia menjalani kegiatan yang bernuansa Islam hanya di saat-saat tertentu saja misalnya acara syawalan warga kampung, pengajian akbar karena terlibat dalam kepanitiaan, atau acara-acara lain yang sifatnya kebersamaan. Sekedar bisa hadir dalam acara keagamaan, dalam kadar pemahaman mereka, itu sudah sangat cukup. Berdasarkan wawancara penulis dengan salah seorang warga pendatang yang beragama Islam, bapak Sukirno (45 th), dijelaskan bahwa sampai saat ini kebersamaan warga kampung Potorono masih sangat kental. Perbedaan agama, tidak membatasi jarak komunikasi. Bila ada acara hajatan di kampung, misalnya kenduren, tahlilan atau yasinan, warga yang meskipun berbeda agama dan berbeda visi keislamannya tetap turut berpartisipasi. Dari sini bisa dilihat bahwa kehadiran warga nonmuslim dalam acara tahlilan merupakan kehadiran secara sosial tetapi tidak secara ritual, atau justru hadir secara ritual sebagai tradisi rutin tapi tidak paham makna keagamaannya. Kalau memang ada warga yang keberatan dan tidak bisa mengikuti tradisi tersebut, ketidakhadirannya akan dijelaskan dan disampaikan kepada warga. Warga juga bisa menghargai dan sampai saat ini pula tidak ada diskriminasi terhadap seseorang atau sekelompok orang karena alasan tersebut.

Tabel 2. Persentase Warga Berdasarkan Perbandingan Penganut Agama.

\begin{tabular}{|l|r|c|}
\hline Wilayah & Muslim & Non Muslim \\
\hline RT 1 & $90 \%$ & $10 \%$ \\
\hline RT 2 & $90 \%$ & $10 \%$ \\
\hline RT 3 & $95 \%$ & $5 \%$ \\
\hline
\end{tabular}

* Data dari Arsip Dusun Potorono. 
Begitu pula pendapat bapak Suyitno (58 th), beliau warga asli kampung Potorono yang beragama Katholik. Sebagai warga nonmuslim yang minoritas, bapak Suyitno tidak pernah merasa terdiskriminasi. Bertahun-tahun dia tinggal di Potorono bahkan dari kecil, beliau tidak pernah merasa terganggu. Sebagai penganut Kristiani, bapak Suyitno juga tetap terlibat dalam acara- acara ritual agama Islam seperti kenduren, tahlilan, yasinan, syawalan dan lainlain. Bagi beliau, itu merupakan sarana sosial untuk bersilaturahim dengan warga sekitar. Yang terpenting adalah bagaimana hati tetap menjaga keyakinan, toh pada dasarnya Tuhannya pun juga sama, Tuhan Yang Maha Esa.

Menurut bapak Darma (41 tahun), sebagai tokoh agama, beliau memandang bahwa keberagamaan masyarakat Potorono berbeda dengan keberagamaan masyarakat perkotaan yang sudah tertata. Mereka menjalani ritual sebagaimana dilakukan oleh pendahulunya. Misalnya shalat dan puasa tetap dilaksanakan, tapi juga melakukan ritual budaya seperti nyadran, mertidusun, memasang kemenyan dan bunga-bunga pada upacara menjelang pemakanan. Mayoritas Islam jawa yang masih abangan dan menganggap asal itu baik, maka tidak salah untuk diterapkan.

Masih menurut bapak Darma, bahwa keberadaan pendatang memberi warna baru bagi penduduk asli dalam menjalankan ritual keagamaan. Sebagian besar para pendatang mempunyai pemahaman agama yang lebih memadahi dibanding penduduk asli. Pendekatan agama yang dilakukan oleh para pendatang, disesuaikan dengan kadar pemahaman masyarakat, sehingga tidak terjadi pergesekan yang berarti. Pengarahan dan ceramah keagamaan juga rutin dilakukan, respon masyarakat baik, tapi memang dibutuhkan waktu untuk menindaklanjuti ke arah pemahaman yang lebih baik. Meski demikian, lazimnya dalam sebuah interaksi, pasti pernah terjadi konflik internal justru sesama muslim sendiri, namun dengan memberi ruang dialog untuk membangun kesadaran dan pengertian atas satu masalah tertentu, konflik itu bisa teratasi.

Narasumber berikutnya yaitu saudara Syamsudin (27 tahun), sebagai ketua Pemuda dan penduduk asli dia sangat merasakan warga yang guyub rukun dalam menjalani kegiatan di kampung, baik itu kegiatan agama maupun kegiatan masyarakat. Misalnya acara pengajian pemuda rutin tiap bulan, dari hari ke hari anggotanya semakin banyak, bahkan ada beberapa pemuda/ pemudi yang beragama non Islam juga turut hadir. Terutama dalam kegiatan Hari Besar Islam, seperti syawalan, pengajian umum, takbiran maupun Idul kurban, semua pemuda pemudi terlibat meski hanya dalam kepanitiaan. Demikian juga bila ada satu keluarga non Islam mengadakan acara sembahyangan misalnya, yang lain juga terlibat dalam urusan teknis. Intinya dalam kampung ini, bahkan sejak dia kecil tidak pernah ada ketegangan antar penganut agama.

Menurut Kepala Dusun Potorono bapak Bronto (53 tahun), ada 3 faktor yang mendukung terciptanya kerukunan umat beragama di kampung Potorono ini yaitu a). Dominasi masyarakat Islam abangan cenderung menerima ideologi apapun asal tidak menyalahkan dan menghakiminya, b). Pengertian yang cukup tinggi dari masyarakat baru sebagai pendatang, c). Kemauan dan kesadaran kedua belah pihak untuk beriteraksi secara sehat dan menjaga agar tidak terjadi kegaduhan sosial. Para pejabat dusun/ desa juga senantiasa mengingatkan bahwa, a). Kedamaian hendaknya selalu dijaga supaya tidak saling merugikan, b). Meyakinkan kepada penduduk bahwa masing-masing orang mempunyai hak dan keyakinan yang berbeda. Menurut bapak Bronto, sampai saat ini tidak ada konflik agama yang menimbulkan ketegangan sosial.

Sebagaimana dalam hubungan antar agama, hubungan secara sosial kemasyarakatan terjalin dengan lebih luwes dan fleksibel. Luwes dalam arti tidak pernah ada ketegangan yang berarti dalam berinteraksi, fleksibel berarti kalangan mana saja bisa 
turut membaur tanpa ada diskriminasi perbedaan. Sebelum mencermati bagaimana dinamika interaksi warga Kampung Potorono dalam kegiatan-kegiatan sosial, bisa dilihat dahulu Tabel 3.

Tabel 3. Persentase Warga Berdasarkan Perbandingan Jumlah Penduduk Asli dan Pendatang

\begin{tabular}{|l|l|l|}
\hline & Penduduk Asli & Pendatang \\
\hline RT 1 & $60 \%$ & $40 \%$ \\
\hline RT 2 & $80 \%$ & $20 \%$ \\
\hline RT 3 & $70 \%$ & $30 \%$ \\
\hline
\end{tabular}

- Data diambil berdasarkan perhitungan kasar, hasil wawancara dengan Kepala Dusun setempat.

Tabel 3 menjelaskan tentang perbandingan jumlah penduduk asli dan pendatang. Penduduk asli dengan jumlah lebih besar dari pendatang, bisa mengakomodir dan menjalin hubungan baik dengan para pendatang. Dalam berbagai kegiatan kampung, semua berpartisipasi tanpa membedakan mana penduduk asli dan mana pendatang. Misalnya kegiatan yang sifatnya rutin seperti ronda malam, menengok warga yang mondok di rumah sakit, kerja bakti, arisan selapanan sebagai wadah evaluasi, dengar pendapat, curhat, kritik, masukan dan saran, semua terakomodir dalam kegiatan yang dilakukan setiap selapan (perputaran 36 hari berdasarkan hari dan weton). Tidak ada superioritas dalam kegiatan di kampung. Menurut bapak Suyitno, meski ada beberapa pendatang yang kurang bisa bergabung, menurut beliau itu hanya belum mengenal kondisi kampung saja. Bisa juga karena memang sudah memiliki karakter kurang baik yang dibawa ke kampung, atau karena memiliki pemahaman yang berbeda yang tidak sesuai untuk diterapkan di kampung, Semua perbedaan tersebut sejauh ini tidak terlalu berpengaruh terhadap keharmonisan kampung.

Masih menurut bapak Suyitno, keharmonisan warga ini murni atas kesadaran masyarakat yang sudah secara turun temurun, masyarakat yang selalu kompak dan komunikasi lancar sudah diturunkan oleh nenek-neneknya dulu. Apalagi di kampung ini banyak saudara-saudara yang masih satu trah yang menyebar ke RT lain dalam satu kampung. Sehingga sangat mungkin ada beberapa keluarga yang tercatat dalam dua RT yang berbeda karena memiliki tempat tinggal di masing-masing RT tersebut, sehingga bisa ikut aktif dalam kegiatan dimana-mana dan menambah persaudaraan terutama menjalin hubungan dengan pendatang baru.

Untuk memenuhi kebutuhan hidupnya, warga kampung Potorono memiliki profesi dan matapencaharian yang berbedabeda. Secara garis besar bisa dilihat Tabel 4.

Tabel 4. Persentase Warga berdasarkan Profesi dan Mata Pencaharian

\begin{tabular}{|l|l|l|l|l|}
\hline & $\begin{array}{l}\text { Petani/ } \\
\text { Wiraswasta }\end{array}$ & $\begin{array}{l}\text { Karyawan/ } \\
\text { Buruh }\end{array}$ & PNS & Lain-lain \\
\hline RT 1 & $70 \%$ & $15 \%$ & $10 \%$ & $5 \%$ \\
\hline RT 2 & $60 \%$ & $10 \%$ & $10 \%$ & $20 \%$ \\
\hline RT 3 & $65 \%$ & $10 \%$ & $10 \%$ & $15 \%$ \\
\hline
\end{tabular}

- Data diambil dari arsp Dusun Potorono tahun 2010.

Dalam kaitannya dengan profesi dan matapencaharian, tidak ada kesenjangan berarti. Kegiatan menengok orang sakit misalnya, di kalangan ibu-ibu PKK, bila ada salah satu anggota keluarga yang sakit dan opname di rumah sakit, ibu-ibu menyumbang masing-masing minimal Rp. 5000,- dan secara rombongan ke rumah si sakit setelah pulang dari rumah sakit. Biasanya kabar disebar lewat sms atau dari pengeras suara masjid. Ibu2 yang punya kesempatan menjenguk si sakit minimal mencapai jumlah 20 orang. Sehingga sangat sering terjadi, rumah si sakit yang sempit bahkan terkesan kumuh, tidak mampu menampung para tamu. Kondisi ini dijalani dari tahun ke tahun dengan tanpa memandang pekerjaan, status, agama, atau profesi si sakit. Demikian juga kegiata arisan RT yang dilakukan secara bergiliran 
tiap bulannya, membaur antara warga kampung dengan warga perumahan. Tidak ada diskriminasi kaya miskin, pendatang atau penduduk asli, Islam atau non Islam. (Wawancara dengan Ibu Warni, Pengurus PKK Dusun Potorono).

Ketua Pemuda Syamsudin mengatakan, bahwa ada kalanya konflik-konflik internal muncul ketika menjelang pemilu atau pemilihan pejabat pemerintahan yang lain, misalnya pilkades atau pilkadus. Kondisi ini wajar karena masing-masing orang pasti mempunyai orang yang dijagokan yang sangat mugkin berbeda dengan warga yang lain. Atau ketika musim kampanye partaipartai, perbedaan itu akan tampak dan saling mengunggulkan jagonya masing-masing. Namun karena kesadaran bermasyarakat yang sangat baik, apalagi sudah terjalin sejak kecil dan bahkan mempunyai hubungan famili (terutama untuk penduduk asli), kondisi tersebut hanya sebatas prosesi itu berlangsung saja. Setelah pesta demokrasi selesai, semua kembali normal kembali.

Menurut bapak Bronto selaku Kepala Dusun Potorono, kesadaran masyarakat akan pentingnya kerukunan ini sudah terbina bertahun-tahun, sehingga sudah menjadi satu pembiasaan yang akhirnya menular ke beberapa pendatang yang turut berbaur. Kondisi ini tentu saja meringankan beban aparat kampung. Berbagai kegiatan rutin yang diadakan secara bersamaan dalam satu kampung adalah syawalan, mertidusun dan safari Ramadan yang dilakukan oleh pejabat desa/dusun dari masjid ke masjid, dari mushola ke mushola untuk mensosialisaikan program kegiatan Kampung. Acara syawalan diadakan di masjid seusai shalat Iedul Fitri di lapangan. Semua warga tanpa kecuali hadir untuk saling memaafkan. Dalam hal ini bahkan yang beragama non Islam turut bergabung. Sedangkan acara mertidusun sebenarnya adalah acara tradisi tahunan, namun pelaksanaannya disesuaikan dengan kondisi setempat. Acara ini bertujuan untuk membersihkan desa dari halhal yang negatif. Dengan mengadakan wayangan sehari semalam, yang dananya dihimpun dari sumbangan warga.
Dari pengamatan peneliti dan penjelasan dari beberapa warga Kampung Potorono, bisa dipastikan tidak pernah terjadi pergesekan antar agama terutama agama mayoritas yaitu Islam dengan agama Kristen dan Katholik sebagai agama yang lain. Kegiatan-kegiatan yang bersifat keagamaan seperti kenduren, tahlilan, yasinan dan syawalan diikuti oleh seluruh komponen agama termasuk yang Kristen dan Katholik. Dengan penuh kesadaran mereka yang minoritas berpartisipasi dan meyakini bahwa kegiatan tersebut hanya merupakan sarana untuk mempererat hubungan antar masyarakat. Terkait dengan hal-hal yang bersifat ibadah, meskipun secara fisik warga nonmuslim kadang terlibat, namun secara spiritual dan keyakinan, mereka tidak terpengaruh. Hal ini sudah berjalan bertahun-tahun, mengingat pluralitas agama dalam masyarakat, bahkan pluralitas dalam satu keluarga bisa dijumpai di wilayah ini.

Perbedaan sikap terkadang muncul justru dari kalangan umat Islam sendiri, di satu sisi menerima kegiatan tersebut sebagai tradisi sebagai ajang silaturahim dan mempererat kebersamaan dengan warga sekitar, di sisi lain sebagian besar pendatang berprinsip bahwa ajaran Islam tersebut sudah tercampur dengan bid'ah (sesuatu yang pada dasarnya tidak ada tuntunannya dalam ajaran Islam). Contohnya kenduren, tahlilan, peringatan tiga hari, nyatus (seratus hari) atau nyewu (seribu hari) dari meninggalnya seseorang atau acara mertidusun. Namun perbedaan sikap tersebut cukup dimaklumi oleh masyarakat terutama penduduk asli yang masih memegang tradisi ini. Selama tidak dihakimi secara frontal dan para pendatang bisa mengerti dengan tradisi yang sudah turun temurun ini, masyarakat pun bisa mengerti bahwa hak seseorang mempunyai prinsip yang berbeda dalam menyikapi sesuatu. Warga yang tidak sepakat dengan kegiatan tersebut juga tidak frontal dalam menyikapinya, mereka bisa berpartisipasi dalam kegiatan lain misalnya kerja bakti, ronda malam, kumpulan RT dan kegiatan- kegiatan lain yang bisa mengakrabkan warga. 
Melihat fenomena tentang Islam pada penduduk asli Potorono, nuansa kejawen masih sangat terasa dan sampai sekarang masih bisa dirasakan. Masyarakat muslim pendatang yang mempunyai pandangan berbeda, meski tidak sepakat dengan ajarannya, namun cenderung harus mampu memaknai perbedaan tersebut dalam konteks sosial. Di sinilah kaum pendatang dituntut untuk tetap menghargai tradisi yang sudah berjalan. Jika shohibul hajat adalah kalangan pendatang muslim, biasanya kemasan acaranya dibuat berbeda tanpa menampilkan nuansa kejawen yang dianggapnya bidah. Dalam kondisi ini masyarakatlah yang dituntut untuk bisa memahami tatacara tuan rumah.

Kegiatan ritual yang biasa dilakukan penduduk asli bisa berjalan tanpa terkikis oleh budaya global dan ajaran Islam yang dianggap syar'i. Penerapan Islamnya masih terkesan di permukaan saja, karena belum banyak tersentuh oleh ajaran-ajaran Islam yang sifatnya doktrinal. Begitu juga pendatang yang notabene berpendidikan tinggi termasuk dalam pendidikan agamanya, mereka sadar sebagai pendatang harus menyesuaikan dengan kondisi setempat. Secara bertahap, tanpa bermaksud menggurui, para pendatang juga mengajak penduduk asli untuk ikut berbaur dalam acara pengajian rutin yang diadakan sebulan sekali.

Konteks masyarakat Islam Jawa pada dasarnya tidak berbeda dengan teori Clifford Geertz yang membagi masyarakat Jawa ke dalam tiga varian yaitu abangan, santri dan priyayi (Geertz ,1960). Bidikan teori ini bisa mewakili masyarakat Jawa yang secara umum mengisyaratkan bahwa lapisan terdasar dari orang Jawa adalah kejawen. Dalam konteks penerapan agamanya, mereka disebut kaum abangan. Mereka memahami ajaran Islam dalam konteks tradisi yang berlaku secara turun temurun. Hanya saja menurut peneliti, ketiga varian tersebut tidak bisa dikotak-kotakkan secara terpisah. Jika itu terjadi yang justru akan muncul adalah konflik internal karena pemberlakuan kasta-kasta seperti halnya dalam agama Hindu.
Masyarakat Potorono meskipun sebagian besar penduduk aslinya masih dianggap abangan, namun tidak memisahkannya dari varian lain yakni santri maupun priyayi. Sebagaimana penilaian Andrew Beatty bahwa Geertz dianggap terlalu berlebihan dalam melukiskan jarak antara ketiga varian tersebut. Beatty memandangnya sebagai entitas yang saling menyapa. Jika selametan atau kenduren dalam pandangan Geertz sebagai bentuk ritual kalangan abangan, Beatty melihatnya justru sebagai ritual bersama, dimana keragaman berkumpul membentuk harmoni dengan membiarkan masing-masing kelompok memaknai menurut perspektifnya sendiri (Beatty, 2001 : 80). Hal inilah yang terjadi pada masyarakat Kampung Potorono. Mayoritas penduduk asli mengaku beragama Islam, namun keyakinan-keyakinan lain tidak bisa diabaikan begitu saja. Ini karena menempatkan Islam pada kejawaan mereka yaitu harmoni sosial, perlindungan nenek moyang dan tradisi leluhur.

Terhadap fenomena tersebut peneliti sepakat dengan teori Geertz yang menempatkan agama sebagai sistem budaya. Ketika agama ditempatkan dalam ruang sosial, setiap orang memberi makna yang berbeda. Simbol tidak mewakili salah satu golongan, karena setiap simbol memiliki rentangan makna yang setiap orang bebas untuk memilihnya. Bukan sebuah konsensus, tapi sebuah kompromi dan sintesa sementara. Diibaratkan sebagai sebuah alunan irama, setiap unsur mengalunkan nadanya sendiri sendiri, sesekali masing-masing ingin mendominasi, tapi seluruhnya menciptakan keseimbangan antara ketenangan dan ketegangan, antara konflik dan harmoni. (Geertz : 1973 ).

Dalam dinamika sosial kemasyarakatan, unsur-unsur perbedaannya lebih komplek dibanding dilihat dari dimensi agama. Perbedaan tersebut meliputi perbedaan status sosial yang kaya dan miskin, pegawai dan buruh, pegawai dan ibu rumah tangga, petani dan pedagang, pengusaha dan pendidik dan lain-lain. Semua perbedaan tersebut bisa dilebur setelah menyatu dalam satu 
kegiatan di kampung tanpa terbelenggu oleh status sosial. Penghormatan penduduk terhadap seseorang yang ditokohkan tidak terlalu mengkultus dan berjalan wajar, hal ini disebabkan karena seseorang yang dianggap tokoh tersebut juga tidak membatasi diri dengan ketokohannya. Dia terjun langsung dengan masyarakat dalam berbagai kegiatan baik itu kegiatan agama maupun kegiatan rutin masyarakat seperti kerja bakti, kumpulan RT, ronda malam dan kegiatan- kegiatan lain yang bermakna sosial. Para tokoh masyarakat maupun pendatang selalu berusaha memberikan konstribusi positif bagi perkembangan kampungnya.

Kepedulian terhadap warga yang terkena musibah, tetap terbina dan terkoordinir dengan baik. Misal ada keluarga yang kesripahan (ada salah satu keluarga yang meninggal), masingmasing keluarga akan dimintai sumbangan wajib sebesar Rp. $5000,-$. Sumbangan wajib tersebut sebagai bentuk kepedulian atas nama dusun atau RT setempat, bila nantinya hadir di acara pemakaman, masing-masing orang atas nama pribadi akan mewujudkan kepedulian dalam bentuk uang atau sembako. Menurut pengamatan peneliti, pola interaksi yang terjalin sangat wajar dan natural tanpa ada sekat, terutama kepedulian ketika ada anggota keluarga yang sakit. Ibu-ibu akan menengok secara bersama-sama dengan memberikan sedikit tali kasih sebagai bentuk perhatian. Hal ini tidak akan didapatkan dalam masyarakat perkotaan yang sudah mengalami pergeseran budaya. Tidak ada diskriminasi bagi si sakit maupun si penengok, meskipun yang sakit orang yang dianggap miskin, atau orang kaya sekalipun, kepedulian ini tetap berjalan. Hal ini juga tidak terlepas dari peran ketua atau pengurus PKK yang selalu menginformasikan kepada yang lain bila ada keluarga yang sedang tertimpa musibah. Keguyuban ini tidak akan berjalan bila antarwarga mempunyai konflik mendalam. Kalau toh mungkin ada konflik masih dalam tataran permukaan, karena itu tidak mempengaruhi kebersamaan dalam masyarakat. Hubungan kekerabatan dalam masyarakat juga sangat berpengaruh bagi keberlangsungan kerukunan warga. Banyak nilai-nilai yang terimplementasi dalam hubungan sosial kemasyarakatan ini antara lain, kebersamaan, kepedulian, kesetaraan dan kesadaran individu untuk menjaga kerukunan hidup dalam masyarakat.

Dari penggambaran tersebut bisa dikatakan bahwa proses interaksi dalam masyarakat kampung Potorono hampir tidak menemui hambatan meskipun ada perbedaan agama, sosial, ekonomi maupun perbedaan antara penduduk asli dan pendatang. Semua bisa berjalan seimbang dengan kesadaran yang tinggi dari masyarakat yang sudah diwarisi oleh nenek moyang mereka seara turun temurun. Beberapa nilai-nilai yang menjaga keseimbangan kehidupan bersama masyarakat Kampung Potorono adalah : 1). Kekerabatan dan Toleransi, kekerabatan memainkan peran yang sangat penting dalam menjaga relasi sosial masyarakat Kampung Potorono. Kesatuan sosial tetap diikat dalam unit-unit kekerabatan. Bisa dilihat bahwa dalam satu keluarga atau antar famili memeluk agama yang berbeda-beda, ataupun perbedaan status sosial tidak merenggangkan ikatan kekerabatan yang terjalin. Yang terjadi justru menumbuhkan sikap toleransi yang tinggi tanpa mempertimbangkan aspek perbedaan agama maupun perbedaan status sosial. 2). Kebersamaan, meskipun ada komunitas pendatang yang menempati wilayah Kampung Potorono, namun hampir tidak ada sekat denan penduduk asli dalam menjalankan rutinitas sosial bahkan rutinitas agama. Penduduk asli dan pendatang tidak pernah memisahkan diri dari yang lain. Kerja bakti, ronda malam, menengok orang sakit dan kegiatan-kegiatan yang lain selalu dilakukan bersama-sama tanpa membedakan asal usul, agama maupun status sosial. 3). Kepedulian, kepedulian yang tinggi dirasakan dalam berbagai momentum misalnya ada penduduk yang sakit, meninggal, melahirkan, sunatan, pergi atau pulang haji dan lain lain. Kepedulian ini selain diwujudkan dalam bentuk tali kasih berupa materi, juga dalam bentuk perhatian yang tulus dari 
masyarakat. Salah satu contoh, ada orang tua warga pendatang meninggal dunia, yang berdomisili di luar kota. Tanpa merasa terbebani pihak warga menyewa satu bus menuju lokasi dengan membebaskan siapa saja yang bersedia ikut dipersilakan. Hal ini sudah menjadi agenda kegiatan sosial di Kampung. 4). Saling Menghormati, tanpa ada sikap saling menghormati, semua unsur perbedaan tidak akan bisa lebur dalam satu nuansa keseimbangan. Masing-masing individu mempunyai sikap toleran dan saling menghargai terhadap segala jenis perbedaan yang ada. Hal ini yang bisa meminimalisir terjadinya konflik, termasuk ketika terjadi konflik kecil dalam pemilu atau pilihan lurah setempat. Konflik yang terjadi hanya kondisional dan tidak menimbulkan permusuhan berkepanjangan. Atau ketika ada perpedaan persepsi dalam memaknai ajaran Islam, warga dituntut untuk memberikan sikap saling menghormati atas hal-hal yang menjadi keyakinan warga, dengan tanpa memaksa atau sebaliknya mengucilkan.

\section{SIMPULAN}

Dari Pembahasan pada bab-bab sebelum ini bisa diperoleh kesimpulan sebagai berikut:

1. Proses interaksi yang terjalin dalam masyarakat terjadi secara bertahap dan berkelanjutan, mengingat banyak warga pendatang yang satu demi satu berdatangan, otomatis penyesuaian akan berjalan terus menerus baik bagi warga baru maupun warga lama. Dalam tahap adaptasi tersebut pasti akan ada dinamika dalam pelaksanaannya. Interaksi tersebut terjalin lewat berbagai kegiatan di kampung baik kegiatan keagamaan maupun kegiatan sosial kemasyarakatan. Semua unsur masyarakat menyatu tanpa ada sekat pembatas secara struktural maupun secara sosial dan agama.

2. Kesadaran masyarakat yang tinggi akan pentingnya kerukunan sudah terbentuk dan tertanam secara turun temurun dari pendahulu-pendahulunya. Dalam hal ini perbedaan agama maupun perbedaan status sosial bukan kendala untuk menyatu dalam kebersamaan. Di samping itu, penduduk asli yang mayoritas masih saling mempunyai hubungan kekerabatan, sangat mendukung terciptanya keharmonisan di kampung. Nilai-nilai yang sudah terbentuk ini secara tidak langsung akan berpengaruh bagi pendatang yang secara kuantitas lebih sedikit dibanding penduduk asli.

3. Pengertian yang cukup tinggi dari berbagai pihak baik penduduk asli maupun pendatang, pegawai maupun buruh, muslim dan non muslim, pejabat dusun dan rakyat biasa, sangat mendukung terciptanya kerukunan. Dengan demikian nilainilai seperti, kebersamaan, kepedulian, toleransi, saling menghargai dan menghormati bisa terimplementasi dengan baik dan natural tanpa direkayasa.

\section{DAFTAR PUSTAKA}

Andrew Beatty, ( 2001), Variasi Agama Jawa : Suatu Pendekatan Antropologi, Jakarta, Murai Kencana

Clifford Geertz, "Religion as a Cultural System" dalam Clifford Geertz, The Interpretation of Cultures, New York : Basic Group, 1973. Press

Badan Pusat Statistik (2010) Penduduk Menurut Wilayah dan Agama yang Dianut. Diambil dari http://sp2010.bps.go.id

Faisal Ismail, (2002). Pijar-pijar Islam: Pergumulan Kultur dan Struktur, Yogyakarta: Lesfi.

Louis O. Kattsoff,( 1989). Pengantar Filsafat, terj. Soerjono Soemargono, Yogyakarta: PT. Tiara Wacana. 
L.J. Maleong, (1991). Metodologi Penelitian Kualitatif, Bandung: Remaja Rosdakarya.

Miles, M.B. \& A.M. Huberman, (1992). Qualitative Data Analysis: A Sourcebook of New Methods, Beverly Hills : SAGE.

Mochtar Bukhori, (1993). Riset Partisipatoris Riset Pembebasan, Jakarta: Gramedia.

Varma, S.P.(1982), Teori Politik Modern, Jakarta, Rajawali Press.

Data Arsip Dusun Potorono 2010

Data dari Biro Pusat Statistik Kabupaten Bantul 2010.

\section{IMPLEMENTASI KONVENSI ANTI DISKRIMINASI PEREMPUAN DALAM POLITIK HUKUM INDONESIA}

Oleh:

Halili

\section{Universitas Negeri Yogyakarta}

Email: halili@uny.ac.id

\begin{abstract}
Abstrak
Penelitian ini bertujuan untuk mengkaji implementasi Konvensi Anti Diskriminasi terhadap Perempuan (Convention on the Elimination of all forms of Discrimination Against Women/CEDAW) dalam politik hukum Indonesia pada umumnya. Selain itu, juga untuk mengkaji kelemahankelemahan dalam politik hukum Indonesia yang terkait dengan perlindungan terhadap perempuan sebagaimana digariskan dalam Konvensi tersebut.

Penelitian ini merupakan studi literer yang ditulis dengan menggunakan pendekatan kualitatif-deskriptif. Sumber data penelitian ini adalah jenis paper. Teknik pengumpulan data yang digunakan adalah studi literature dan dokumentasi. Instrumen penelitian ini adalah peneliti sendiri dengan bantuan chek list dan recording note. Check list dan recording note tersebut digunakan untuk melacak dan merekam data yang dihasilkan melalui studi literatur dan dokumentasi. Pengujian keabsahan data menggunakan triangulasi. Langkah-langkah analisis yang digunakan dalam penelitian ini adalah analisis data kualitatif, meliputi reduksi data, display data, kesimpulan dan verifikasi.

Hasil penelitian ini menunjukkan: 1) Konvensi Anti Diskriminasi Perempuan tersebut sudah mulai dilaksanakan secara parsial melalui beberapa peraturan perundang-undangan, antara lain UU Kesehatan, UU Pemberantasan Tindak Pidana Perdagangan Orang, UU Paket Politik yang terdiri dari UU Pemilihan Umum DPR, DPD, dan DPRD, UU Pemilihan Presiden, UU Partai Politik, dan UU Penyelenggara Pemilihan Umum). 2) Implementasi Konvensi tersebut berimplikasi pada dua kecenderungan. Pertama, munculnya kecenderungan politik afirmatif bagi perempuan dalam berbagai bidang. Perempuan ditempatkan sebagai identitas yang membutuhkan pengakuan khusus atau istimewa secara formal dibandingkan dengan laki-laki. Kedua, mencoloknya warna aliran hukum feminis dalam hukum positif. Hukum positif merupakan turunan
\end{abstract}

